\title{
KIẾN THỨC, THÁI Độ VÀ THỰC HÀNH DINH DƯỡNG CỦA BÊ̂NH NHÂN TẮNG HUYẾT ÁP
}

\section{TÓM TẮT}

Muc tiêu: Mô tả kiến thức, thái đô và thực hành dinh đưỡng của bệnh nhân tăng huyết áp điều trị tại Bệnh viện Trường Đại học Y khoa Vinh năm 2020. Phương pháp nghiền cứu: Nghiên cứu mô tả cắt ngang được thực hiện để khảo sát kiến thức, thái độ và thực hành về dinh dưỡng của 112 bênh nhân tăng huyết áp nguyên phát điêu trị tại bệnh viện Trường Đại học Y khoa Vinh. Kết quả: 112 bệnh nhân tăng huyết áp nguyên phát được nghiên cứu trong đó nam giới chiếm 58,0\%. Về kiến thức dinh dưỡng cho bệnh nhân tăng huyết áp: $74,0 \%$ biết không ăn mặn; $64,3 \%$ biết hạn chế rượu bia và hút thuốc lá; $32,0 \%$ biết hạn chế thức ăn nhiều dầu mõ̃. Tỷ lệ bệnh nhân cho rằng các yếu tố có nguy cơ cao cho bệnh nhân tăng huyết áp: hút thuốc lá $(84,0 \%)$, uống rượu bia $(85,7 \%)$, thói quen ăn mặn $(90,1 \%)$ và thừa cần béo phì $(58,1 \%)$. Về thực hành dinh dưỡng: $82,1 \%$ còn sử dụng thường xuyên thức ăn chiên xào; $22,3 \%$ thường xuyển uống rượu bia và $19,6 \%$ có thói quen hút thuốc lá. Kết luận: Nghiên cứu đã chỉ ra rằng mặc dù bệnh nhân đã được tiếp cân với các thông tin về chế độ dinh dưỡng dành cho bệnh nhân tăng huyết áp. Nhưng còn có một tỷ lệ cào bệnh nhân chưa có kiến thức, thái độ và thực hành đúng về chế độ dinh dưỡng dành cho bệnh nhân tăng huyết áp. Cán bộ y tế cần sát sao hơn trong công tác truyền thông giáo dục sức khỏe về chế độ dinh dưỡng cho bệnh nhân tăng huyết áp huyết áp

Tư khóa: kiến thức, thái độ, thực hành, tăng

\section{SUMMARY \\ KNOWLEDGE, ATTITUDES AND PRACTICES REGARDING NUTRITION OF PATIENTS WITH HYPERTENSION}

Objectives: To describe the nutritional knowledge, attitudes and practices of patients with hypertension who were treated at Vinh Medical University Hospital in 2020. Methods: A crosssectional descriptive study was used to investigate the nutritional knowledge, attitudes and practices of 112 patients with hypertension who were treated at Vinh Medical University Hospital. Results: 112 patients with primary hypertension were studied, of which $58,0 \%$ was male. Regarding nutritional knowledge of patients with hypertension: do not eat salty food $(74,0 \%)$, limit alcohol consumption and smoking $(64,3 \%)$, limit greasy foods $(32,0 \%)$. The patients

*Trường Đại học Y khoa Vinh Chịu trách nhiệm chính: Nguyễn Văn Tuấn Email: tuanminh1975@gmail.com Ngày nhận bài: 2.3.2021

Ngày phản biện khoa học: 26.4.2021

Ngày duyệt bài: 5.5.2021

\section{Nguyễn Văn Tuấn*, Trần Thị Anh Tho**}

who assume the following factors are high risk factors for patients with hypertension: smoking $(84,0 \%)$, drinking alcohol $(85,7 \%)$, salty eating habits $(90,1 \%)$ and overweight and obesity $(58,1 \%)$. Regarding nutritional practices: $82,1 \%$ still regularly use fried foods; $22,3 \%$ of them regularly drink alcohol and $19,6 \%$ have a smoking habit. Conclusion: The research has shown that although patients have had access to information about diet for patients with hypertension. But there is also a high proportion of patients who have the uncorrect knowledge, attitudes and practices of diet for patients with hypertension. Health workers need to be more close in communication and education about nutrition for patients with hypertension.

Keywords: knowledge, attitude, practice, hypertension

\section{I. ĐĂT VẤN ĐỀ}

Tăng huyết áp là nguyên nhân hàng đâu của bệnh lý tim mạch và tử vong trên toàn thế giới. Tỷ lệ tăng huyết áp không ngừng gia tăng, đặc biệt ở các nước có thu nhập thấp và trung bình. Ước tính vào năm 2010, có khoảng 31,1\% người trưởng thành trên thế giới bị tăng huyết áp [5]. Ở Việt Nam, số liệu điêuu tra qua các năm cho thây: năm 2010 ở miền Bắc là 16,4\%, riêng thành phố Hà Nội có tỷ lê 23,3\%; đến năm 2011 tại thành phố Hồ Chí Minh là 20,5\% và Thừa Thiên Huế là 22,8\%. Mặc dù đã có nhiều cải thiện trong việc nâng cao nhận thức, điều trị và kiểm soát tăng huyết áp. Tuy nhiên, tỷ lệ bệnh nhân bị tăng huyết áp không được chẩn đoán và không được kiểm soát vẫn còn là một vấn đề đối sức khỏe cộng đồng, để lại nhiều biến chứng nghiêm trọng như suy tim, tai biến mạch máu não, bệnh thận mạn,...

Tăng huyết áp là tình trạng có thể kiểm soát được bằng thuốc và thay đổi lối sống. Các biện pháp thay đổi lối sống được khuyến cáo cho thấy có khả năng làm giảm huyết áp bao gồm: hạn chế ăn muối, giảm uống rượu bia, ăn nhiêu rau và các thực phẩm ít chất béo, giảm cân và tập thể dục thường xuyên [3].

Tại thành phố Vinh - tỉnh Nghệ An số bệnh nhân bị tăng huyết áp ngày càng gia tăng, nên việc tìm hiểu kiến thức, thái độ, thực hành dinh dưỡng của bệnh nhân là rất cân thiết để có biện pháp can thiệp phù hợp nhằm kiểm soát tốt hớn tình trạng tăng huyết áp cho người bệnh. Xuất phát từ vấn đề đó chúng tôi tiến hành nghiên cứu đề tài này với mục tiêu: Mô tả kiến thức, thái độ và thực hành dinh dưỡng của bệnh nhân 
tăng huyết áp điều trị tại Bệnh viện Trường Đại học Y khoa Vinh năm 2020.

\section{II. ĐỐI TƯỢNG VÀ PHƯƠNG PHÁP NGHIÊN CỨU}

2.1. Đối tượng nghiên cứu. Bệnh nhân tăng huyết áp nguyển phát được khám và điều trị tại Bệnh viện Trường Đại học Y khoa Vinh năm.

\subsubsection{Tiêu chuẩn lựa chọn}

- Bệnh nhân được chẩn đoán tăng huyết áp nguyên phát theo Khuyến cáo về chẩn đoán và điêu trị tăng huyết áp 2018 của Hội tim mạch Quốc gia Việt Nam [1].

- Bệnh nhân đồng ý tham gia nghiên cứu.

2.1.2. Tiêu chuẩn loai trừ: Bệnh nhân bị suy giảm khả năng giao tiểp, không có khả năng tự trả lời câu hỏi.

2.2. Thời gian và địa điểm nghiên cứu

2.2.1. Thời gian nghiên cứu: từ tháng 6/2020 đến hết tháng 12/2020

2.2.2. Địa điểm nghiên cứu: Bệnh viện Trường Đại học $Y$ khoa Vinh.

\subsection{Phương pháp nghiên cứu}

2.3.1. Thiết kế nghiên cứu: Nghiên cứu mô tả cắt ngang

2.3.2. Cỡ mẫu: 112 bệnh nhân phù hợp tiêu chuẩn nghiên cứu trong thời gian nghiên cứu.

2.3.3. Kỹ thuật tiến hành trong nghiên cứu

- Thiết kế phiếu điều tra: Phiếu điều tra được thiết kế thành 4 mục lớn:

Mục A: gồm 9 câu hỏi ( $A 1$ đến $A 9)$ liên quan đến đặc điểm chung của bệnh nhân.

Mục B: gồm 8 câu hỏi (B1 đến B8) liên quan đến kiến thức về chế độ dinh dưỡng của bệnh nhân tăng huyết áp.

Mục C: gồm 5 câu hỏi (C1 đến C5) liên quan đến thái độ về chế độ dinh dưỡng của bệnh nhân tăng huyết áp.

Mục $D$; gồm 11 câu hỏi ( $D 1$ đến $D 11$ ) liên quan đến thực hành về chế độ dinh dưỡng của bệnh nhân tăng huyết áp.

- Đo huyết áp đúng quy trình kỷ thuật.

- Đo chiêu cao:

Phương tiện: Thước đo chiêu cao.

Bệnh nhân chân không đi dày dép, đứng thằng, mắt nhìn thằng, 3 điểm chạm thành sau của thước là chẩm, mông và gót chân.

Đơn vị tính là mét $(\mathrm{m})$

- Đo cân nặng:

Phương tiện: Cân bàn Trung quốc được hiệu chinh

\subsection{Kiến thức về chế độ dinh dưỡng của bệnh nhân tăng huyết áp}

\section{Bảng 3.2. Kiến thức cơ bản của bênh nhân về bênh THA}

Tiêu chí

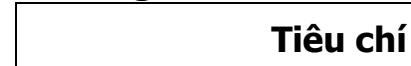

Bệnh nhân: Chỉ mặc quần áo lót mõng.

Đơn vị tính: ki lô gam $(\mathrm{kg})$

- Tính chỉ số khối cơ thể ( BMI)

$$
\text { BMI = - }{\text { Chiêu } \mathrm{cao}^{2}(\mathrm{~m})}^{-}
$$

Kết quả: Gầy : BMI < 18,5

Trung bình: BMI từ 18,5 đến 22,9

Béo phì: $B M I \geq 23$

- Đo vòng bụng:

Phương tiện: Thước dây vải

Vị trí đo: Đo qua chỗ lớn nhất của vòng bụng

Đơn vị tính: $\mathrm{cm}$

Có nguy cơ: $N a m \geq 90 \mathrm{~cm}$, Nữ $\geq 80 \mathrm{~cm}$.

2.4. Xử lý số liệu: - Số liệu được xử lý bằng phần mềm SPSS 20.0 .

- Sử dụng ANOVA test để so sánh trung bình các quan sát nếu biến có phân bố chuẩn.

- Sử dụng test $x 2$ để so sánh sự khác biệt về tỷ lệ phần trăm.

\section{KẾT QUẢ NGHIÊN CỨU}

3.1. Đặc điểm chung của đối tượng nghiên cứu

Bảng 3.1. Đặc điểm chung của đôi tượng nghiên cứu

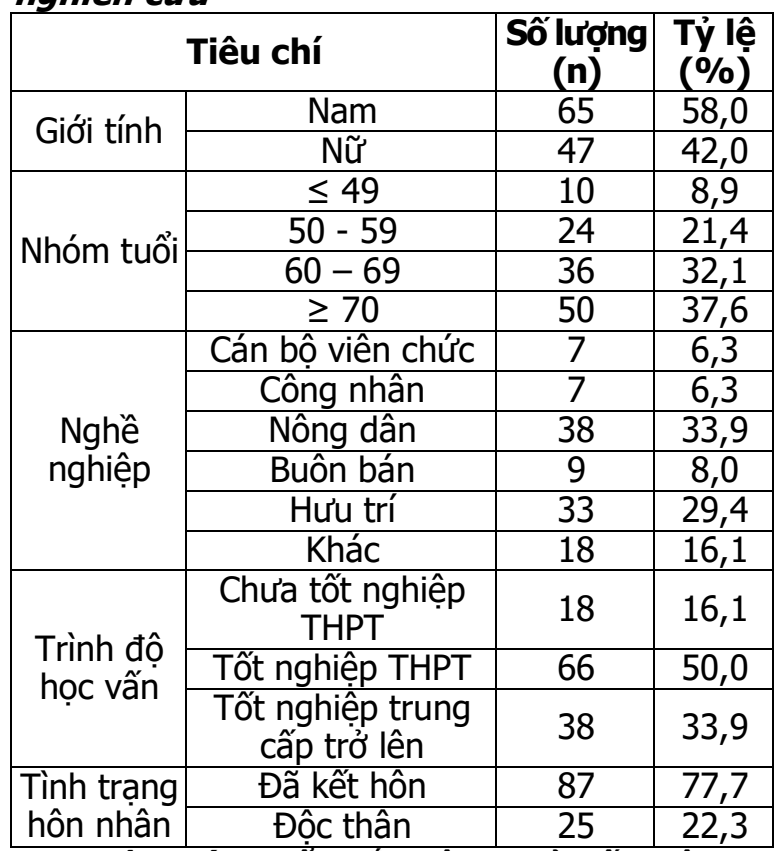

Nhận xét: Tuối mắc bệnh chủ yếu trên 60 tuổi, đa số bệnh nhân có trình độ học vấn từ tốt nghiệp trung học phổ thông trở lển.

Số lượng (n) Tỷ lệ (\%)

Không

Số lượng (n) $\mid$ Tỷ lệ(\%)




\begin{tabular}{|c|c|c|c|c|}
\hline $\begin{array}{c}\text { Được nghe các thông tin về bệnh THA } \\
\text { hoặc cách phòng chống THA }\end{array}$ & 92 & 82,1 & 29 & 25,9 \\
\hline Biết các yếu tố nguy cơ gây bệnh THA & 63 & 56,3 & 49 & 43,7 \\
\hline Biết cách phòng bệnh THA & 87 & 77,7 & 25 & 22,3 \\
\hline Àn nhạt tốt cho người bị THA & 83 & 74,1 & 20 & 17,9 \\
\hline
\end{tabular}

Nhânn xét: Tỷ lệ bệnh nhân đã nghe về các thông tin về bệnh tăng huyết áp và cách phòng bệnh tăng huyết áp khá cao.

Bảng 3.3. Biêt các yêu tố nguy cơ gây bệnh THA của đối tượng nghiên cứu

\begin{tabular}{|c|c|c|}
\hline Tiêu chí & $\begin{array}{c}\text { Số lượng } \\
\text { (n) }\end{array}$ & $\begin{array}{c}\text { Tỷ lệ } \\
(\mathbf{\%})\end{array}$ \\
\hline Hành vi hút thuốc lá & 52 & 46,4 \\
\hline Hành vi uống rượu bia & 52 & 46,4 \\
\hline Thừa cân, béo phì & 20 & 17,9 \\
\hline Stress & 25 & 22,3 \\
\hline Mắc bệnh đái tháo đường & 22 & 19,6 \\
\hline Thói quen ăn mặn & 52 & 46,4 \\
\hline İt hoạt động thế lực & 18 & 16,1 \\
\hline
\end{tabular}

Nhâan xét: Trong số các yếu tố nguy cơ của bênh THA, thì 3 yếu tố mà bênh nhân biết đến nhiều nhất là hút thuốc lá, uống rượu bia và thói quen ăn mă̆n.

Bảng 3.4. Biêt về các biện pháp phòng bệnh THA của đôi tượng nghiên cứu

\begin{tabular}{|c|c|c|}
\hline Tiêu chí & $\begin{array}{c}\text { Số lượng } \\
\text { (n) }\end{array}$ & $\begin{array}{c}\text { Tỷ lề } \\
(\mathbf{\%})\end{array}$ \\
\hline Rèn luyện thế dục thế thao & 63 & 56,3 \\
\hline $\begin{array}{c}\text { Không uống rượu bia, hút } \\
\text { thuốc là }\end{array}$ & 72 & 64,3 \\
\hline Hạn chếăn thứcăn nhî̀u dâu mỡ & 36 & 32,1 \\
\hline Hạn chế ăn mạn & 72 & 64,3 \\
\hline Àn nhiều rau xanh, hoa quả & 20 & 17,9 \\
\hline Duy trì cân nặng hợp lý & 22 & 19,6 \\
\hline
\end{tabular}

Nhân xét: Trong số các biện pháp phòng bệnh THA thì bênh nhân biết đến nhiêu nhất là 3 biện pháp: không uống rượu bia, hút thuốc lá và hạn chế ăn mặn.

Bảng 3.5. Các nguồn thông tin cung cấp kiến thức dinh dưỡng cho bênh nhân của đôî tượng nghiên cứu

\begin{tabular}{|c|c|c|}
\hline Nguồn thông tin & $\begin{array}{c}\text { Số } \\
\text { Iượng } \\
\text { (n) }\end{array}$ & $\begin{array}{c}\text { Tỷ lệ } \\
\text { (\%) }\end{array}$ \\
\hline Ti vi & 83 & 74,1 \\
\hline Báo chí & 36 & 32,1 \\
\hline Cán bộ y tế & 38 & 33,9 \\
\hline Người thân & 78 & 69,4 \\
\hline Tố chức đoàn thế & 54 & 48,2 \\
\hline
\end{tabular}

Nhận xét. Trong số các nguồn thông tin cung cấp về kiến thức dinh dưỡng cho bệnh nhân THA thì nguồn từ tivi chiếm nhiều nhất (74,1\%), nguồn từ cán bộ y tế chỉ chiểm 33,9\%.

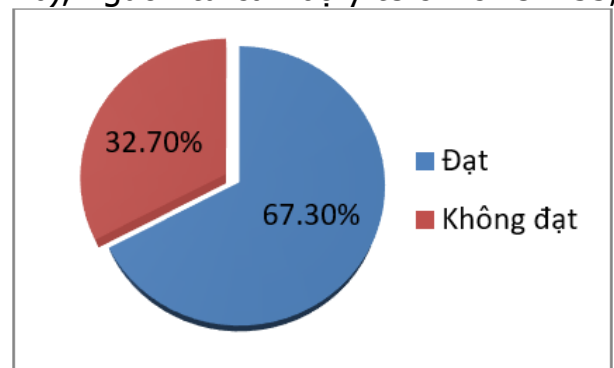

Biểu đồ 3.1. Kiến thức của đối tượng nghiên cứu về chế đô dinh dưỡng cho bênh nhân THA

Nhân xét: Có $67,3 \%$ số bệnh nhân có kiến thức đúng về dinh dưỡng dành cho người bị tăng huyết áp.

3.3. Thái độ về chế độ dinh dưỡng của đối tượng nghiên cứu

Bảng 3.6. Thái độ của bệnh nhân về chế độ dỉnh dưỡng của đôî̉ tượng nghiên cứu

\begin{tabular}{|c|c|c|c|c|c|c|}
\hline \multirow{2}{*}{ Tiêu chí } & \multicolumn{2}{|c|}{ Đồng ý } & \multicolumn{2}{|c|}{ Không đồng ý } & \multicolumn{2}{|c|}{ Không ý kiến } \\
\hline & $\begin{array}{l}\text { Số lượng } \\
\text { (n) }\end{array}$ & $\begin{array}{l}\text { Tỷ lê̂ } \\
(\%)\end{array}$ & $\begin{array}{l}\text { Số lượng } \\
\text { (n) }\end{array}$ & $\begin{array}{l}\text { Tỳ lệ } \\
(\%)\end{array}$ & $\begin{array}{l}\text { Số lượng } \\
\text { (n) }\end{array}$ & $\begin{array}{l}\text { Tỷ lệ } \\
(\%)\end{array}$ \\
\hline $\begin{array}{c}\text { Hút thuốc là là yếu tố nguy } \\
\text { cơ cao gây ra THA }\end{array}$ & 94 & 84,0 & 9 & 8,0 & 9 & 8,0 \\
\hline $\begin{array}{l}\text { Uống rượu bia là là yếu tố } \\
\text { nguy cớ cao gây ra THA }\end{array}$ & 96 & 85,7 & 6 & 5,4 & 10 & 8,9 \\
\hline $\begin{array}{c}\text { Thửa cân béo phì là là yếu tố } \\
\text { nguy cơ cao gây ra THA }\end{array}$ & 65 & 58,1 & 22 & 19,6 & 25 & 22,3 \\
\hline $\begin{array}{l}\text { Thói quen ăn mặn là là yếu } \\
\text { tố nguy cơ cao gây ra THA }\end{array}$ & 101 & 90,1 & 4 & 3,6 & 7 & 6,3 \\
\hline $\begin{array}{c}\text { Stress là là yếu tố nguy cơ } \\
\text { cao gây ra THA }\end{array}$ & 45 & 40,2 & 20 & 17,9 & 47 & 41,9 \\
\hline
\end{tabular}

Nhân xét: Tỷ lệ cao bênh nhân đồng ý với việc hút thuốc lá, uống rượu bia và thói quen ăn mặn là yếu tố nguy cơ cao của bệnh THA. 


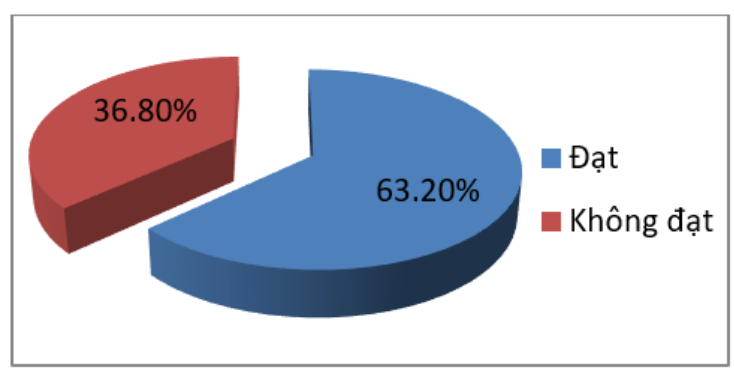

Biểu đồ 3.2. Thái độ của đối tượng nghiên cứu về chế độ dinh dướng cho bệnh nhân THA

Nhận xét: $63,2 \%$ có thái độ đúng về chễ độ dinh dưỡng dành cho bệnh nhân THA.

3.4. Thực hành về chế độ dinh dưỡng của bệnh nhân tăng huyết áp

Bảng 3.7. Thực hành về chế độ dinh dưỡng của đôî tượng nghiên cứu

\begin{tabular}{|c|c|c|c|c|}
\hline \multirow{2}{*}{ Tiêu chí } & \multicolumn{2}{|c|}{ Có } & \multicolumn{2}{c|}{ Không } \\
\cline { 2 - 5 } & Số lượng(n) & Tỷ lệ (\%) & Số lượng(n) & Tỷ lệ(\%) \\
\hline Thường xuyên sử dụng thức ăn chiên xào & 92 & 82,1 & 20 & 17,9 \\
\hline Thói quen hút thuốc lá & 22 & 19,6 & 90 & 80,4 \\
\hline Thói quen uống rượu bia & 25 & 22,3 & 87 & 77,7 \\
\hline Thói quen tập thể dục & 96 & 85,7 & 16 & 14,3 \\
\hline
\end{tabular}

Nhân xét: Bệnh nhân có thói quen thường xuyên sử dụng thức ăn chiên xào còn chiếm tỳ lệ cao $(82,1 \%)$

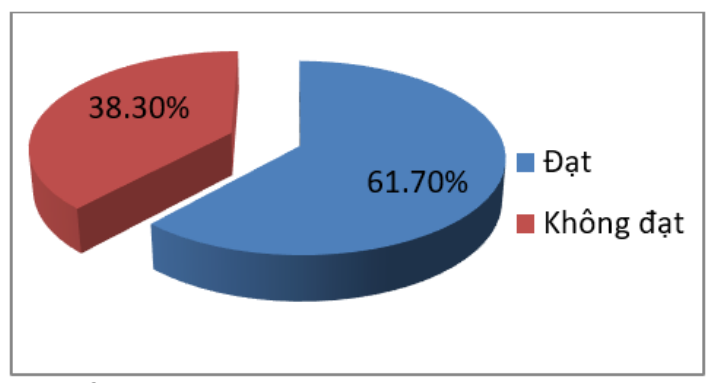

Biểu đồ 3.3. Thực hành của đôî tượng nghiên cứu về chế độ dỉnh dưỡng

Nhận xét: $61,7 \%$ số bệnh nhân có thực hành dinh dưỡng đúng dành cho bệnh nhân THA.

\section{BÀN LUÂN}

4.1. Kiến thức về dinh dưỡng dành cho bệnh nhân tăng huyết áp của đối tượng nghiên cứu. Trong nghiên cứu này, $82,1 \%$ số bệnh nhân được nghe các các thông tin về bệnh tăng huyết áp và cách phòng bệnh tăng huyết áp. Điều này cho thấy đa số bệnh nhân có tìm hiểu về các vấn đề liên quan đến tăng huyết áp một cách chủ động. Trong nghiên cứu cũng cho thấy có $43,7 \%$ không biết các yếu tố nguy cơ tăng huyết áp, điều này có thể do bệnh nhân không nhớ về vấn đề này mặc dù đã được nghe về các thông tin liên quan đến bệnh tăng huyết áp.

Một chế độ ăn giảm mặn và duy trì đủ lượng kali sẽ̃ có lợi cho việc kiểm soát huyết áp [4]. Số bệnh nhân biết chế độ ăn nhạt có lợi cho việc kiểm soát huyết áp trong nghiển cứu của chúng tôi chiếm tỷ lệ cao là $74,1 \%$.

Trong số các yếu tố nguy cơ gây bệnh tăng huyết áp thì bệnh nhân biết đến nhiều nhất là 3 yếu tố gồm hút thuốc lá, uống rượu bia và thói quen ăn mă̆n. Nghiên cứu của Lê Đức Hạnh và cộng sự (2013) [2] thì tỷ lệ bệnh nhân biết về thói quen ăn mặn là $21,74 \%$ thấp hơn trong nghiên cứu của chúng tôi là $46,4 \%$. Kiến thức của bệnh nhân về hút thuốc là là một yếu tố nguy cơ tim mạch ở bệnh nhân tăng huyết áp trong nghiên cứu của chúng tôi là $46,4 \%$ thấp hơn trong một nghiên cứu của Shibiru Tesema và cộng sự (2016) [7] trên người Ehiopia là $83,8 \%$ còn kiến thức về uống bia rượu là yếu tố nguy cơ ở bệnh nhân THA trong nghiên cứu này là $59,9 \%$ cũng cao hơn trong nghiên cứu của chúng tôi là 46,4\%. Tỷ lệ bệnh nhân biết stress là yếu tố nguy cơ gây THA là $22,3 \%$, đái tháo đường là $19,6 \%$. Yếu tố nguy cơ ít hoạt động thể lực được biết đến với tỷ lệ thấp là 16,1\%, nghiên cứu của Nguyễn Thị Kiệm năm 2013 là $87 \%$.

Trong số các biện pháp phòng bệnh THA thì bệnh nhân biết đến nhiều nhất là không uống rượu bia, không hút thuốc và hạn chế ăn mă̆n. Tỷ lệ bệnh nhân biết về biện pháp không uổng rượu bia, không hút thuốc và hạn chế ăn mặn là 64,3\%. Trong một nghiên cứu của Nguyễn Văn Út và cộng sự năm 2007 tại bệnh viện Nguyễn Tri Phương thì tỷ lệ này là $69,7 \%$. Tỷ lệ bệnh nhân biết đến biện pháp tập luyện là $56,3 \%$. Đáng chú ý là tỷ lệ bệnh nhân biết đến duy trì cân nặng hợp lý chỉ có tỷ lệ thấp là 19,6\%.

Phương pháp cung cấp thông tin cho người bệnh đóng vai trò quan trọng trong hiệu quả của cồng tác truyền thông giáo dục sức khỏe. Các biện pháp cung cấp thông tin gián tiếp có ưu điểm là có khả năng phổ biến rộng, cung cấp 
thông tin một lúc cho nhiêu người và đõ̃ tốn kém nhưng có nhược điểm là thông tin một chiều. Ngược lại, phướng pháp cung cấp thông tin trực tiếp đặc biệt là sự tư vấn của cán bộ y tế cho bệnh nhân có ưu điểm là thông tin hai chiều, giúp bệnh nhân nắm rõ vấn đề hơn và tuân thủ thực hiện hơn. Trong nghiên cứu của chúng tối tỷ lệ bệnh nhân được cung cấp thông tin qua tivi chiếm tỷ lệ cao nhất là $74,1 \%$, còn thông tin được cung cấp bởi cán bộ y tế còn tương đối thấp là 33,9\%. Trong một nghiên cứu của Udaya Ralapanawa và cộng sự (2020) ở Sri Lanka cho thây $70 \%$ bệnh nhân được nhận thông tin về chế độ dinh dưỡng cho người tằng huyết áp từ cán bộ y tế [8]. Nghiên cứu cứu của Shibiru Tesema và cộng sự (2016) tỷ lệ bệnh nhân được cung cấp kiến thức về dinh dưỡng bởi cán bộ y tế là $90,7 \%$ [7].

Khi đánh giá về kiến thức về dinh dưỡng dành cho bệnh nhân tăng huyết áp chúng tôi nhận thấy có $67,3 \%$ số bệnh nhân có kiến thức đúng về dinh dưỡng cho bệnh nhân tăng huyết áp. Tỷ lệ này là hơn $75 \%$ trong nghiên cứu của Udaya Ralapanawa và cộng sự (2020) ở Sri Lanka [8].

4.2. Thái độ về dinh dưỡng dành cho bệnh nhân tăng huyết áp của đối tượng nghiên cứu. Trong nghiên cứu của chúng tôi thái độ đồng ý với việc tránh hút thuốc là $84,0 \%$, uống rượu bia là $85,7 \%$, tránh ăn mặn là $90,1 \%$. Trong nghiên cứu của Shibiru Tesema và cộng sự (2016) thì $80 \%$ bệnh nhân cho rằng cần tránh ắn mặn khi bị tăng huyết áp và chỉ $15 \%$ cho rằng cần giảm tiêu thụ rượu khi bị tăng huyết áp. Trong nghiên cứu của Nurl Fatin Binti Buang và cộng sự (2019) ở Malaysia cho thấy $63,3 \%$ đồng ý kiểm tra huyết áp nếu như họ hút thuốc lá [6]. Nghiên cứu của Nguyễn Văn Ửt và cộng sự năm 2006 thì 96,7\% đồng ý với việc ăn mặn là yếu tố nguy cơ gây ra tăng huyết áp.

Quan điểm của bệnh nhân về stress là yếu tố nguy cơ gây ra tăng huyết áp, trong nghiên cứu của chúng tôi có $40,2 \%$ có thái độ đồng ý với vấn đề trên. Trong nghiên cứu của Nurl Fatin Binti Buang và cộng sự (2019) ở Malaysia thì tỷ lệ này là $87,3 \%$ [6].

Khi đánh giá thái độ chung của bệnh nhân về chế độ dinh dưỡng thì có $63,2 \%$ bệnh nhân có thái độ đúng về chế độ dinh dưỡng dành cho bệnh nhân tăng huyết áp, còn 38,3\% bệnh nhân có thái độ chưa đúng về chế độ dinh dưỡng dành cho bệnh nhân tăng huyết áp. Chỉ 58,1\% bệnh nhân đồng ý với việc thữa cân béo phì là yếu tố nguy cơ của bệnh nhân tăng huyết áp,
19,6\% không đồng ý và 22,3\% số bệnh nhân được khảo sát không có ý kiến về vấn đề này.

4.3. Thực hành về dinh dưỡng dành cho bệnh nhân tăng huyết áp của đối tượng nghiên cứu. Trong nghiên cứu của chúng tôi thì số bệnh nhân thường xuyên sử dụng thức ăn chiên xào là $82,1 \%$. Điều này có thể do bệnh nhân không biết đến tác động xấu của thức ăn chiên xào đối với bệnh nhân tăng huyết áp hoặc có thể bệnh nhân đã biết nhưng do thói quen của người bệnh trong chế độ ăn. Vì vậy cần phải tăng cường công tác tư vấn về một chế độ ăn lành mạnh cho người bệnh tăng huyết áp trong cộng đồng cũng như mối khi đi khám bệnh.

Số bệnh nhân có thói quen hút thuốc là trong nghiên cứu của chúng tôi là 19,6\%, tương tự như nghiên cứu của Nguyễn Thị Kiệm năm 2013 ở bệnh nhân tăng huyết áp tại bệnh viện đa khoa tỉnh Hà Tĩnh. Số bệnh nhẩn không có thói quen này là $80,4 \%$. Trong nghiên cứu của Nurl Fatin Binti Buang và cộng sự (2019) ở Malaysia thì số bệnh nhân có thực hành không hút thuốc là $82,7 \%$ [6].

Bệnh nhân có thói quen tập thể dục đều đặn chiếm tỷ lệ $85,7 \%$ trong nghiên cứu của chúng tôi. Tỷ lệ này trong nghiên cứu của Shibiru Tesema và cộng sự (2016) là 67,7\% [7]. Trong nghiên cứu của chúng tôi $77,7 \%$ bệnh nhân tăng huyết áp không lạm dụng rượu bia. Đánh giá thực hành chung về chế độ dinh dưỡng dành cho bệnh nhân tăng huyết áp, trong nghiên cứu của chúng tôi nhận thây có $61,7 \%$ số bệnh nhân có thực hành đúng về chế độ dinh dưỡng và $38,3 \%$ số bệnh nhân có thực hành chưa đúng về chế độ dinh dưỡng dành cho bệnh nhân tăng huyết áp.

\section{KẾT LUẬN}

Nghiên cứu đã chỉ ra rằng mặc dù bệnh nhân đã được tiếp cận với các thông tin vể chế độ dinh dưỡng dành cho bệnh nhân tăng huyết áp. Nhưng còn có một tỷ lệ cao bệnh nhân chưa có kiến thức, thái độ và thực hành đúng về chế độ dinh dưỡng dành cho bệnh nhân tăng huyết áp. Cán bộ y tế cần sát sao hơn trong công tác truyền thông giáo dục sức khỏe về chế độ dinh dưỡng cho bệnh nhân tăng huyết áp

\section{TÀI LIÊU THAM KHẢO}

1. Hội Tim mach Quốc Gia Việt Nam (2018), Khuyến cáo về chẩn đoán và điêu trị tăng huyết ap 2018.

2. Lê Đức Hạnh (2013), Nghiên cứu một số yếu tố nguy cớ, sự hiểu biết về bệnh và chể độ an của bệnh nhân tăng huyết áp. Tạp chí Y học thực hà̀nh. 2/2013. 
3. Appel LJ (2003), Lifestye Modification as a means to Prevent and Treat high blood pressure. J Am SocNephrol. 14: p. 99-102.

4. Francesco Fantin, et al. (2019), The Importance of Nutrition in Hypertension. Nutrients. 11: p. 25-42.

5. Katherine T. Mills, Andrei Stefanescu, Jiang He (2020), The global epidemiology of hypertension. Nature Reviews Nephrology. 16: p. 223-237.

6. Nurul Fatin Binti Buang, Nor Azlina A Rahman, Mainul Haque (2019), Knowledge, attitude and practice regarding hypertension among residents in a housing area in Selangor, Malaysia. Original Research. 92: p. 145-152.

7. Shibiru Tesema, et al. (2016), Knowledge, Attitude and Practice Regarding Lifestyle Modification of Hypertensive Patients at Jimma University Specialized Hospital, Ethiopia. Primary Health Care. 6(1): p. 1-2.

8. Udaya Ralapanawa, et al. (2020), Hypertension Knowledge, Attitude, and Practice in Adult Hypertensive Patients at a Tertiary Care Hospital in Sri Lanka. Research Article. 2020.

\section{ĐẶC ĐIỂM DİCH TỄ CỦA NGộ ĐộC CẤP MộT Số MA TÚY MớI TẠI TRUNG TÂM CHỐNG Độ̉C BỆNH VIỆN BACH MAI}

\section{TÓM TẮT}

Muc tiêu: Mô tả đă̆c điểm dich tễ của bênh nhân ngộ độc ma túy mới tại Trung tâm Chống độc Bệnh viện Bạch Mai. Đối tượng và phương pháp: Nghiên cứu mô tả 72bệnh nhần ngộ độc ma túy mới không phải nhóm opi điều trị tại Trung tâm Chống độc Bệnh viện Bạch Mai từ tháng 1/2017 đến 6/2019. Kết quả: Chủ yểu gặp ở Nam giới $(72,2 \%)$; tuổi trung bình là $30,57 \pm 9,3$ năm; người thất nghiệp $73,6 \%$; trình độ trung học phổ thông trở xuống $65,3 \%$; người độc thân $65,3 \%$; sống ở thành phố $59,7 \%$ và nông thổn $40,3 \%$. Một số loại ma túy mới thường gặp là Amphetamin (29,2\%), MET (22,2\%), MDMA (19,4\%), THC $(20,8 \%)$, Ketamin $(8,3 \%)$; chú yếu bệnh nhân dùng đường uống $(79,2 \%)$, đường hút, hít là $20,8 \%$. Bệnh nhân dùng ma túy do nghiện $(54,2 \%)$, được rủ $(26,4 \%)$, do thói quen $(19,4 \%)$; sử dụng tại vũ trường và địa điểm đông người $(58,3 \%)$, tại nhà $(41,7 \%)$; thường dùng vào ban đêm (72,2\%); dùng cùng người khác $(62,5 \%)$. Có $81,9 \%$ đã từng sử dụng ma túy trước đó và $18,1 \%$ ngô độc ở lần đâu sử dung. Kết luận: Đánh giá đặc điểm dịch tễ của ngộ độc ma túy cần thiết để xác định mô hình bệnh tật, giúp chẩn đoán và xử trí cấp cứu cho các bệnh nhân.

Tư khóa: ngộ độc ma túy

\section{SUMMARY \\ EPIDEMIOLOGY CHARACTERISTICS OF PATIENTSWITH DRUGS OF ABUSE POISONING AT POISON CONTROL CENTER BACHMAI HOSPITAL}

Objective: $\quad$ to describeepidemiology characteristics from patients with drugspoisoning. Subjects and Methods: Anobservational study

\footnotetext{
${ }^{1}$ Trung Tâm Chông Độc Bệnh viện Bạch Mai

${ }^{2}$ Trường Đại học Y Hà Nội

Chịu trách nhiệm chính: Đặng Thị Xuân

Email: xuandangthi@bachmai.edu.vn

Ngày nhận bài: 4.3.2021

Ngày phản biên khoa học: 23.4.2021

Ngày duyệt bài: 5.5.2021
}

\section{Đặng Thị Xuân ${ }^{1}$, Hà Trần Hưng ${ }^{1,2}$}

included 72 poisoned non-opium drugs patients treated at the Poison Control Center, Bach Mai Hospital from 1/2017 to 6/2019.Results:mostly accured in male with $72.2 \%$; the average age was $30.57 \pm 9.3$ years old; unemployed people $73.6 \%$; $65.3 \%$ below high school level; single people $65.3 \%$; living in city $59.7 \%$ and rural $40.3 \%$. Some common new drugs were Amphetamine (29.2\%), MET $(22.2 \%)$, MDMA (19.4\%), THC (20.8\%), Ketamine $(8.3 \%) ;$ Mainly used oral route $(79.2 \%)$, suction, inhalation was $20.8 \%$. Due to addiction (54.2\%), invited $(26.4 \%)$, habit $(19.4 \%)$; used at discos and crowded places $(58.3 \%)$, at home $(41.7 \%)$; usually used at night $(72.2 \%)$; shared with others $(62.5 \%)$ There were $81.9 \%$ people had used drugs before and $18.1 \%$ got poisoned at the first time use. Conclusion: Evaluating the epidemiological characteristics of drugs poisoning is necessary to identify disease patterns, essential for early diagnosis and management of patients.

Key words: drugs of abuse poisoning

\section{I. ĐĂT VẤN ĐỀ}

Ma túy là một vấn đề nhức nhối của xã hôi trong nhiều năm qua. Nghiện ma túy tại Việt Nam vẫn đang diển biến phức tạp với chiều hướng ngày càng gia tăng, số người nghiện đang ở cộng đồng chiếm tỉ lệ 64,5\% [1]. Trước đây, nhóm opi chiếm 3/4 chất gây nghiện thường được sử dụng. Thời gian gần đây các loại ma túy mới không phải nhóm opi được sử dụng ngày càng nhiều, như các loại ma túy tổng hợp, cần sa, ketamin, bóng cười. Cơ cấu người nghiện ma túy theo vùng miền cũng thay đổi đáng kể. Nếu như giữa những năm 90 của thế kỷ trước, nghiện ma túy chủ yếu phổ biến ở người dân tại các tỉnh miền núi phía Bắc thì từ giữa những năm 2000 đã tăng mạnh xuống vùng đồng bằng sông Hồng và khu vực miền Đông Nam Bộ. Cách thức sử dụng ma túy cũng có nhiều thay đổi, trước kia chủ yếu là chích hút thì hiện tại các ma túy mới có nhiều 